\title{
A COMPARATIVE ANALYSIS OF THE ROMANIAN CULTURAL ENVIRONMENT FROM 2005 TO 2020
}

\author{
Andrei PUNGAN ${ }^{a^{*}}$ \\ ${ }^{a}$ Bucharest University of Economic Studies, Romania
}

DOI: $10.24818 / \mathrm{IMC} / 2020 / 03.15$

\begin{abstract}
This study analyzes the main changes of the cultural environment in Romania over a period of 15 years, using the data obtained by World Values Survey, through the three waves that followed the main values and beliefs of the Romanian society. Even if changes in the environment and implicitly in culture are normal, this change is extremely slow and can take several decades or even longer.
\end{abstract}

KEYWORDS: cultural environment, national culture, values, beliefs

\section{INTRODUCTION}

From a geographical point of view, Romania is a country situated at the juncture of Central, Eastern and Southeastern Europe. This spatial positioning is transposed by the fact that it is a nation of close to 20 million people, belonging to more than 20 ethnic groups that have their own languages, customs, and traditions.

The entire population of Romania lived - under the communist regime - somewhat culturally closed for 40 years, which led to the strengthening of the ideas and values that composed the cultural environment, and of course those ideas were not fought at all during that period.

In the end, Romania left behind its communist past, and from 2007 is a member of the European Union which gave its citizens the opportunity to observe and be part of other national cultures across the continent and last but not least, has produced changes upon Romania’s own national culture.

\section{CULTURAL ENVIRONMENT OF ROMANIA}

In order to follow the changes of the cultural environment of Romania, we will use the database from the World Values Survey global research project, that studies the core values and beliefs of people from 1981, in close to 100 countries. The data is collected with a standardized questionnaire, having representative national samples in order to measure different aspects of that society over time, through waves that follows a global time period.

In this article we will use the data gathered from 2005 to 2020, comprising the three latest waves or periods, to find out what changes have occurred during that time period.

Table 1 - World Values Survey Database Details

\begin{tabular}{|l|l|l|l|}
\hline Wave & Wave Period & $\begin{array}{l}\text { Questionnaire } \\
\text { year }\end{array}$ & $\mathbf{N}$ \\
\hline Wave 5 & $2005-2009$ & 2005 & 1776 respondents \\
\hline Wave 6 & $2010-2014$ & 2012 & 1503 respondents \\
\hline Wave 7 & $2017-2020$ & 2018 & 1257 respondents \\
\hline
\end{tabular}

Source: Haerpfer et al. (2020), adapted by author

*Corresponding author. E-mail address: punganandrei11@stud.ase.ro 
For the analysis of the cultural environment of Romania, we have chosen "the main aspects of the Romanian cultural environment, as they appear on the representative Romanian sample from the World Values Survey” (David, 2015).

We mention that the cultural environment is a resource for any country, especially if we consider that the phenomenon of globalization increasingly diminishes cultural differences because it is increasing cross-cultural exchanges.

Table 2 - List of followed questions

\begin{tabular}{|l|l|}
\hline Question & Followed Aspect \\
\hline $\begin{array}{l}\text { 1. Can you please answer if you: } \\
\text { I see myself as an autonomous individual: }\end{array}$ & Strongly agree \\
\hline $\begin{array}{l}\text { 2. Can you please answer if you: } \\
\text { I see myself as part of my local community: }\end{array}$ & Strongly agree \\
\hline 3. Would you say that ........ is vital for you? & Work \\
\hline 4. Would you say that ......... is vital for you? & Religion \\
\hline 5. Would you say that you are ......? & Very happy \\
\hline $\begin{array}{l}\text { 6. Do you consider yourself very proud of your own } \\
\text { nationality? }\end{array}$ & Very proud \\
\hline 7. Do you consider ...... should be learned at home? & Independence \\
\hline 8. Do you consider ...... should be learned at home? & Tolerance and respect for other people \\
\hline 9. Can you say that ......? & Most people can be trusted \\
\hline 10. Emancipative values & Mean \\
\hline \multicolumn{1}{|c|}{ Source: . }
\end{tabular}

Source: Haerpfer et al. (2020); Inglehart et al. (2014)- adapted by author

These ten questions are the ones that characterize the cultural environment of a country like Romania, and will allow us to find any differences that have occurred during a time span of 15 years, especially since important events as the accession to the European Union happened.

Nevertheless, the national culture is influenced by the bidirectional learning relationship between its members, "all group learning ultimately reflects someone's original beliefs and values, their sense of what ought to be, as distinct from what is" (Schein, 2010). Therefore "cultural change is slow for the values. These were learned when we were children, from parents who acquired them when they were children. This makes for considerable stability in the basis values of a society” (Hofstede et al., 2010).

\section{ANALYSIS OF THE CULTURAL ENVIRONMENT CHANGES}

Analyzing the 10 aspects of the questionnaire, over the three periods, we obtain the below results which allow us to have an overview of changes in members' perceptions over time.

Question 1

The degree of individuality of the members is increasing in Romania (+6.2\%), wave 5 versus wave 6. This is somewhat opposite to the fact, that in Romania, we encounter a cultural dimension directed towards collectivism.

Question 2 and 6

People are social beings therefore they need to feel part of a group. For this reason, there is an increasing trend towards being part of a community ( $+3 \%$ each period) and one in which most people are proud of their nationality.

Question 3

The importance of work seems to fluctuate in the Romanian culture, we see an increase in wave 6 (+ $2.4 \%$ ) versus wave 5 . Then we see a significant decrease in wave 7 versus wave 6 , which in the end represents a total decrease of $-8.3 \%$ between 2005 and 2020 . 
Table 3 - Results per Wave

\begin{tabular}{|l|l|l|l|}
\hline Question & $\begin{array}{l}\text { Wave } \\
\mathbf{5}\end{array}$ & $\begin{array}{l}\text { Wave } \\
\mathbf{6}\end{array}$ & $\mathbf{\text { Wave }}$ \\
\hline Q1 & $21.80 \%$ & $28.00 \%$ & $\mathrm{~N} / \mathrm{A}$ \\
\hline Q2 & $39.50 \%$ & $43.00 \%$ & $46.60 \%$ \\
\hline Q3 & $53.50 \%$ & $55.90 \%$ & $45.20 \%$ \\
\hline Q4 & $57.00 \%$ & $50.50 \%$ & $47.30 \%$ \\
\hline Q5 & $7.30 \%$ & $13.60 \%$ & $18.10 \%$ \\
\hline Q6 & $37.40 \%$ & $43.00 \%$ & $46.00 \%$ \\
\hline Q7 & $29.10 \%$ & $42.20 \%$ & $39.60 \%$ \\
\hline Q8 & $58.60 \%$ & $65.20 \%$ & $48.50 \%$ \\
\hline Q9 & $19.30 \%$ & $7.70 \%$ & $11.40 \%$ \\
\hline Q10 & 0.42 & 0.42 & 0.43 \\
\hline
\end{tabular}

Source: Haerpfer et al. (2020); Inglehart et al. (2014)- adapted by author

\section{Question 4}

Overall, we see a decrease of $-9.7 \%$ in the importance of religion in the daily life of people, which could show a trend towards a more secular country.

\section{Question 5}

Psychology tells us that "people's evaluations of their lives and encompasses both cognitive judgments of satisfaction and affective appraisals of moods and emotions” (Kesebir \& Diener, 2008). The most important thing about happiness are the correlations in which it is associated with a healthier life of people.

Therefore, even if in Romania we see an increase of $+10.8 \%$ of respondents that say they are very happy, the overall response is still not satisfactory.

\section{Question 7}

As we know, the values of a culture are passed down from one generation to the next. That is why the fact that independence is being passed on to the new generation $(+10.5 \%)$ represents a distance from a collectivist culture.

Question 8

Tolerance and respect for other people shows the degree to which a culture can accept the cultural differences of people outside it. Consequently, we see a decrease of $-10.1 \%$ of parents who promote this value and pass it on to their children.

Question 9

Trust is a central point of any social group because it binds the members of this group and facilitates cooperation between them. Overall, we notice a decrease of $-7.90 \%$ over the 15 years period, which indicates a continuous decrease in mutual trust between community members.

Question 10

Emancipative values show off the efforts made to help a certain group in need. The mean results in each period have remained pretty much the same, which shows that the efforts to help the members that are outside the central group did not changed or really improved. 


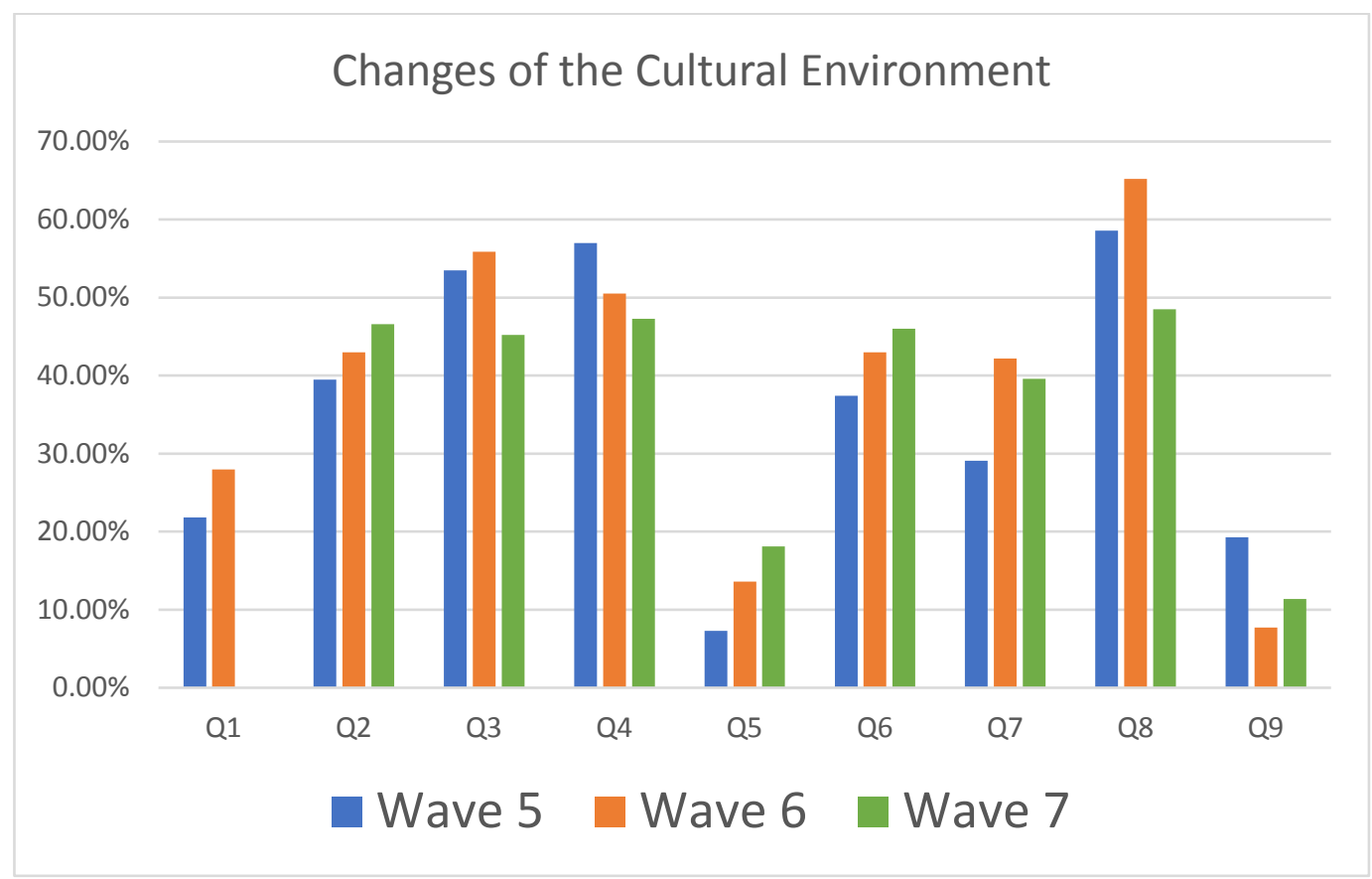

Figure 1 - Graphical results per waves

Source: Haerpfer et al. (2020); Inglehart et al. (2014)- adapted by author

As it can be seen above, every aspect of the Romanian cultural environment fluctuates from period to period (15 years timespan) and we look at only one aspect that remains the same, namely emancipation values.

\section{CONCLUSIONS}

Cultural changes occur over a long period of time, which often span over several generations because both values and beliefs are deeply rooted in the members of a society who in turn pass them on to the next generation as the right way to think, feel and respond in a given context, at one moment in time. In the case of Romania, a society that has been closed to external influences for more than 40 years we meet a culture shock that appeared with the accession to the European Union, through which a bidirectional movement of the population was made inside the European continent, and in Romania foreigners appeared having a different culture, that produced an integration between the different cultures which can be seen in everyday life.

That is why we can conclude that the cultural environment is indeed changing in Romania, but the direction is not clear at the moment, especially since these changes are pursued in a period of time that is too short to properly pursue the entire timeframe of what it really means to change a cultural environment.

\section{REFERENCES}

David, D. (2015). Psihologia poporului roman: profilul psihologic al românilor într-o monografie cognitiv-experimentală. Iași: Editura Polirom.

Haerpfer, C., Inglehart, R., Moreno, A., Welzel, C., Kizilova, K., Diez-Medrano, J. et al. (eds.). (2020). World Values Survey: Round Seven - Country-Pooled Datafile. Madrid, Spain \& Vienna, Austria: JD Systems Institute \& WVSA Secretariat. doi: 10.14281/18241.1

Hofstede, G., Hofstede, G.J. \& Minkov, M. (2010). Cultures and organizations: Software of the mind, 3rd Edition. New York: McGraw Hill Professional. 
Inglehart, R. C., Haerpfer, A., Moreno, C., Welzel, K., Kizilova, J., Diez-Medrano, et al. (eds.). (2014). World Values Survey: Round Six - Country-Pooled Datafile. Madrid:JD Systems Institute.Retrieved September, 2020, from www.worldvaluessurvey.org /WVSDocumentationWV6.jsp].

Inglehart, R. C., Haerpfer, A., Moreno, C., Welzel, K., Kizilova, J., Diez-Medrano, et al. (eds.). (2014). World Values Survey: Round Five - Country-Pooled Datafile. Madrid: JD Systems Institute. Retrieved September, 2020, from www.worldvaluessurvey.org/WVSDocumentation WV5.jsp.

Kesebir, P. \& Diener, E. (2008). In pursuit of happiness: empirical answers to philosophical questions. Perspectives on Psychological Science, 3(2), 117-125. doi: 10.1111/j.17456916.2008.00069.x.

Schein, E. H. (2010). Organizational Culture and Leadership, 4th Ed. San Francisco: Jossey-Bess. 